http://jmscr.igmpublication.org/home/ ISSN (e)-2347-176x ISSN (p) 2455-0450 crossref DOI: https://dx.doi.org/10.18535/jmscr/v9i6.42

\title{
Expression of Androgen Receptor in Invasive Triple Negative Breast Carcinoma
}

\author{
Authors \\ Dr M.Srividya DNB Pathology, Dr Milap Shah MD Pathology, \\ Dr Sachin Johari MD Pathology, Dr Bharat Vaswani MD DM Medical Oncology, \\ Dr K.Srinivas Radiation Oncology, Dr CN.Srikanth MS, MCH Surgical Oncology, \\ Dr Ravindra Vottery MD DM Medical Oncology
}

\section{Introduction}

Breast cancer is the most common female cancer worldwide representing nearly a quarter $(25 \%)$ of all cancers. In India although age adjusted incident rate of breast cancer is lower (25.8 per $100000)$ than U.K(95 per 100000) but mortality is at $\operatorname{par}(12.7$ vs 17.1 per 100000$)$ with U.K. There is significant increase incidence and cancer associated morbidity \& mortality in Indian subcontinent. The age adjusted Incidence rate of Carcinoma of breast was found as high as 41 per 100000 women for Delhi, followed by Chennai (37.9), Bangalore (34.4) \& Thiruvananthapuram district (33.7). ${ }^{1}$

Breast cancer is the most prevalent and lethal malignancy among females worldwide ${ }^{2}$. In 2018, $1,735,350$ incident breast cancer cases are estimated to be diagnosed in the United States of America and 609,640 associated mortalities are anticipated $^{3}$. Incidence of TNBC is $15 \%$ among breast cancers.

Over the last few decades there have been outstanding advances in breast carcinoma management leading to earlier detection of disease
\& development of more effective treatment. Breast cancer is no longer seen as a single disease but rather a multifaceted disease comprised of distinct biological subtype with diverse natural history presenting a varied spectrum of clinical, pathological \& molecular features with different prognostic \& therapeutic implication.

Invasive breast carcinoma effects younger age women, African- american women and women with BRAC-1 mutation. Invasive breast carcinomas are aggressive and invade the surrounding breasttissue. The prognosis for invasive ductal Carcinoma (IDC) depends on the type of breast cancer, tumor Size, spread, the histological grade and hormonal receptors.

Approximately $80 \%$ of breast carcinomas are invasive ductal carcinoma, followed by invasive lobular carcinomas which account for approximately $10-15 \%$ of cases.

In Invasive breast carcinoma malignant cells infiltrate and breech the ductal lining and lobules and enter into breast connective tissue, they have the potential to spread to lymph nodes and other organs as metastasis. ${ }^{4}$ 
Traditionally breast carcinoma is treated with surgery, chemotherapy, radiation, hormonal therapy and targeted therapy. Breast has hormonal receptors namely ER,PR and HER2NEU receptors showing variable expression .About $80 \%$ of breast cancers are ER positive that means cancer cells grow in response to estrogen. About $65 \%$ of breast cancers are PR positive that means cancer cells grow in response to progesterone. Tumours that are ER and PR positive respond to hormonal/endocrine therapy after surgery and chemotherapy are finished. These hormonal therapies are of two types one by blocking ER receptor [tamoxifen] and second one by decreasing the production of hormone [aromatase inhibitors].About $20 \%$ of breast cancer cells show HER2NEU receptor expression, they respond to targeted therapy with Transtuzumab after surgery and chemotherapy.

HER2 is a gene in breast, that makes HER2 proteins. This proteins are receptors on breast cells that help in growth of normal breast tissue. But in 25\% of cases HER2 gene doesn't work and causes HER2 gene amplification, which in turn causes production of excess HER2 proteins. This HER2 gene amplification or overexpression is reported as HER2 positive in pathology reports. ${ }^{5}$

If more than $10 \%$ of cells are HER2 positive the breast cancer is HER2positive. HER2 can be determined by IHC and FISH.

On IHC results can be interpreted as: 0[negative], $1+$ [also negative], 2+[borderline], 3+[positiveHER2 protein overexpression].

On FISH results are interpreted as: positive [HER2 gene amplification] or negative [no HER2 gene amplification]

HER2 positivity was considered when there was IHC positivity of $3+$ [uniform intense complete membrane staining] or a FISH result demonstrating more than 6 copies of HER2 genes per nucleus or FISH ratio of more than 2.2.

HER2 negative result was considered when IHC staining of 0 or $1+$ and a FISH result with less than 4 HER2 gene copies per nucleus or a FISH ratio of less than 1 .
Based on IHC profile breast carcinomas are classified into 4 groups:

1) $\mathrm{ER} / \mathrm{PR}+, \mathrm{HER} 2 \mathrm{NEU}+$

2) $\mathrm{ER} / \mathrm{PR}+$, HER2NEU-

3) ER/PR-, HER $2 N E U+$

4) ER/PR-, HER2NEU-

(TRIPLE NEGATIVE BREAST CANCER TNBC)

The IHC classification correlates well with intrinsic gene expression microarray categorization:

1) $\mathrm{ER} / \mathrm{PR}+$, HER $2 \mathrm{NEU}+$ with luminal $\mathrm{B}$

2) $\mathrm{ER} / \mathrm{PR}+, \mathrm{HER} 2 \mathrm{NEU}$ - with luminal $\mathrm{A}$

3) ER/PR-,HER2NEU+ with HER2NEU over expression

4) ER/PR-, HER2NEU- with basal like ${ }^{7}$

TNBCs are invasive ductal carcinomas in which there is loss of expression of ER, PR and HER2NEU, accounts for $15 \%$ of breast cancer cases $^{8}$. These cancers have worst prognosis, aggressive and low overall survival and low disease free survival period. TNBC lacks the expression of ER, PR and Her2neu receptors hence they need attention.

Histologically TNBCs are mostly invasive carcinomas which are poorly differentiated and high proliferative activity and large primary tumor showing pushing borders, central necrosis and variable degree of lymphocytic infiltrations. These invasive carcinomas are common in young premenopausal women and those arising from BRCA 1 mutations. Patients with TNBC do not benefit from hormonal or transtuzumab-based therapy because of the loss of target receptors such as ER, PR, and HER-2. Hence, surgery and chemotherapy, individually or in combination, appear to be the only available modalities. Treatment of patients with these phenotypes has been challenging because of aggressive behavior. Approximately $10-32 \%$ of TNBC showed androgen receptor signaling in such patients AR blockade would be a potential endocrine treatment.

Androgen receptor is a member of nuclear steroid hormone receptor family, which also include ER 
and PR. Steroid hormone receptor are critical component of signaling pathway and play a crucial role in transcription factors regulating gene expression. Although ER and PR are widely recognized for their prognostic and predictive role in breast cancer, the biological role of $A R$ in breast carcinoma is emerging. The drug development pipeline of AR targeted therapies in prostate cancer is facilitating the evaluation of $A R$ signal inhibition in TNBC including bicalutamide [a non-steroid partial agonist] and enzalutamide [an inhibitor of nuclear localization of AR]. ${ }^{9}$

Expression of EGFR is seen in $15-45 \%$ of breast cancer. Its expression was mainly found in basallike carcinoma .EGFR activation results in cell proliferation, angiogenesis, invasion and metastasis. A majority of triple negative patients have tumors of basal subtype with EGFR expression and poor prognosis.

\section{Materials and Methodology}

Study Design: a crossectional analytical diagnostic study of MRM specimen sampled for routine histopathology at department of pathology yashoda hospital secunderabad.

Sample Size: minimum of 50 cases of breast cancer cases whose IHC interpretation was ER/PR/HER2NEU negative as per ASCO / CAP guidelines.

Sample size was calculated by using simple formula (Daniel 1999):

$$
\mathrm{n}=\frac{\mathrm{Z}^{2} \mathrm{P}(1-\mathrm{P})}{\mathrm{d}^{2}}
$$

where $\mathrm{n}=$ sample size,

$\mathrm{Z}=\mathrm{Z}$ statistic for a level of confidence, for the level of confidence of $95 \%$, which is conventional $\mathrm{Z}$ value is 1.96 .

$\mathrm{P}=$ expected prevalence or proportion (in proportion of one; if $15 \%, \mathrm{P}=0.15$ )

$\mathrm{d}=$ precision (in proportion of one; if $10 \%, \mathrm{~d}=$ $0.10)$.

Study Duration: 2 year study period between July 2017 to June 2019.
Method: A systematic study of Crossectional study of total 50 patients who underwent surgical resection for breast carcinoma at yashoda hospitals from 2017 to 2019 were enrolled in the study.

A single tumor block of paraffin embedded tissue from resected specimens was selected. For construction of tissue microarrays [TMA] the most representative area of tumor was identified on $\mathrm{H}$ and $\mathrm{E}$ slide and marked. A replicate core sample measuring $0.6 \mathrm{~mm}$ in diameter at a spacing of $0.7-0.8 \mathrm{~mm}$ were obtained using a precise instrument, and arrayed on a recipient paraffin block. Using microtomy 4micron thickness sections were cut from TMA blocks and stained for $\mathrm{H}$ and $\mathrm{E}$ to verify the histology. Here we have taken 20 cases on one TMA slide.

For IHC the panel of markers taken were ER, PR, HER2NEU, AR and EGFR.

\section{Procedure}

1] 4micron thickness sections were cut from TMA blocks and attached on polylysine coated slides and incubated at 37 degrees Celsius for two hours.

2] The slides were dewaxed in xyeline and rehydrated in graded alcohols and covered with citrate buffer [pH -6] for 15 minutes.

3] Antigen retrivalwas done in microwave at 600 watt for 15 minutes.

4] Cooled to room temperature and washed with tap water.

5] Peroxidase block was done for 5 minutes.

6] Incubated for 1hour with primary monoclonal antibodies against ER, PR, HER2NEU, AR and EGFR.

7] Washedwith phosphate buffer saline 2-3 times.

8] Polyexcel target binder was added for $15 \mathrm{~min}$.

9] Again washed with phosphate buffer saline 2-3 times.

10] This was followed by incubation with secondary antibody for 15 minutes

11] Washed with PBS 2-3 times

12] DAB (diaminobenzidine) was added for 5minutes.

13] Washed under tap water for 5 minutes. 
14] Counterstained with hematoxylin for 30seconds.

15] Water washed.
16] Dehydrated with xylene and alcohol.

17] Dry the slide and mount with DPX (dextreneplastisizer of xylene)

Table-2 list of primary antibodies

\begin{tabular}{|l|c|c|c|c|c|}
\hline & ER & PR & HER2NEU & AR & EGFR \\
\hline CLONE & EP1 & EP2 & EP3 & EP120 & EP22 \\
\hline SPECIES & Rabbit & Rabbit & Rabbit & Rabbit & Rabbit \\
\hline DILUTION & $1: 100$ & $1: 100$ & $1: 200$ & RTU & RTU \\
\hline CATALOGUE NUMBER & CR042 & CR068 & CR047 & PR002 & PR040 \\
\hline CLONALITY & Monoclonal & Monoclonal & Monoclonal & Monoclonal & Monoclonal \\
\hline SOURCE & pathnsitu & Pathnsitu & pathnsitu & Pathnsitu & Pathnsitu \\
\hline
\end{tabular}

(RTU-ready to use)

Then the sections were assessed for ER, PR and HER2NEU status. ER and PR were assessed based on guidelines provided by Allered method. For ER and PR negative ( $0 \%$ cells positive) was included in study. For HER2NEU ASCO/CAP guidelines were followed, score 0 was taken negative in HER2NEU.

Clinical details like age of the patient, tumor size, grade and lymph node status were collected from case records. The study was conducted after obtaining approval from ethics committee and informed consent from patient.

\section{Statistical Analysis}

The data analysis was done by using SPSS (statistical package for social sciences) windows version 24.0 for statistical analysis.

Qualitative data variables were expressed by frequency / percentages.

Quantitative data variables were expressed by using mean and standard deviation.

To study the association between AR and MIB, age, tumor size, grade, lymph node status and EGFR by chi square test.

Risk estimate with $95 \%$ CI was calculated by odds ratio.

Level of significance was considered as 0.05 .

\section{Results}

56 women aged between 30-75 yrs who were diagnosed with TNBC were assessed for androgen receptor (AR) expression. Among 56 cases 2 were medullary carcinoma, 1 was solid papillary carcinoma and remaining 53 were invasive ductal carcinoma. All the patients underwent mastectomy or lumpectomy as primary treatment. Incidence of TNBC patients at our hospital was $6.5 \%$.

Mean age of TNBC diagnosis was 52yrs. In TNBC cases predominantly tumor size was pT2 (82\%), grade was G3 (73\%) and lymph node status was N0 (58.9\%).

$\mathrm{AR}$ and EGFR were interpreted by immunohistocytochemistry. For AR positivity nuclear staining and for EGFR positivity membranous and cytoplasmic staining was considered. $10 \%$ cut off was taken for AR positivity and $15 \%$ for EGFR. On analysis AR was positive in $21.4 \%$ of cases and EGFR was positive in $58.9 \%$ of cases.

Age

Table-3 frequency distribution of age

\begin{tabular}{|l|c|c|c|c|c|}
\hline & $\mathrm{N}$ & Minimum & maximum & Mean & Std. deviation \\
\hline Age & 56 & 30 & 75 & 52.52 & 11.989 \\
\hline Valid N & 56 & & & & \\
\hline
\end{tabular}


Tumor Size (pT)

Table -4 frequency distribution of tumor size

\begin{tabular}{|c|c|c|c|c|}
\hline & Frequency & Percent & Valid percent & Cumulative percent \\
\hline Valid T2 & 46 & 82.1 & 82.1 & 82.1 \\
\hline T3 & 10 & 17.9 & 17.9 & 100.0 \\
\hline Total & 56 & 100.0 & 100.0 & \\
\hline
\end{tabular}

Grade (G)

Table-5 frequency distribution of tumor grade

\begin{tabular}{|cc|c|c|c|c|}
\hline & & Frequency & Percent & Valid percent & Cumulative percent \\
\hline Valid & G2 & 15 & 26.8 & 26.8 & 26.8 \\
\hline & G3 & 41 & 73.2 & 73.2 & 100.0 \\
\hline Total & 56 & 100.0 & 100.0 & \\
\hline
\end{tabular}

\section{Lymph Node (N)}

Table-6 frequency distribution of lymph node metastasis

\begin{tabular}{|cc|c|c|c|c|}
\hline & & Frequency & Percent & Valid percent & Cumulative percent \\
\hline Valid & N0 & 33 & 58.9 & 58.9 & 58.9 \\
\hline & N1 & 9 & 16.1 & 16.1 & 75.0 \\
\hline & N2 & 8 & 14.3 & 14.3 & 89.3 \\
\hline N3 & 6 & 10.7 & 10.7 & 100.0 \\
\hline Total & 56 & 100.0 & 100.0 & \\
\hline
\end{tabular}

\section{Androgen Receptor (AR)}

Table-7 Frequency distribution of androgen receptor

\begin{tabular}{|c|c|c|c|c|}
\hline & Frequency & Percent & Valid percent & Cumulative percent \\
\hline Valid negative & 44 & 78.6 & 78.6 & 78.6 \\
\hline Positive & 12 & 21.4 & 21.4 & 100.0 \\
\hline total & 56 & 100.0 & 100.0 & \\
\hline
\end{tabular}

\section{EGFR}

Table-8 Frequency distribution of EGFR

\begin{tabular}{|c|c|c|c|c|}
\hline & Frequency & Percent & Valid percent & Cumulative percent \\
\hline Valid negative & 23 & 41.1 & 41.1 & 41.1 \\
\hline Positive & 33 & 58.9 & 58.9 & 100.0 \\
\hline Total & 56 & 100.0 & 100.0 & \\
\hline
\end{tabular}

Table-9: Clinico -pathological correlation of AR positive and AR negative TNBC:

\begin{tabular}{|c|c|c|c|c|}
\hline & Total & AR positive & AR negative & Wilcoxon test P-value \\
\hline \multicolumn{5}{|l|}{ AGE } \\
\hline$<50 \mathrm{yrs}$ & 23 & 4 & 19 & \\
\hline$>50 \mathrm{yrs}$ & 33 & 8 & 25 & 0.393 \\
\hline \multicolumn{5}{|c|}{ TUMOR SIZE } \\
\hline $\mathrm{T} 2$ & 46 & 11 & 35 & \\
\hline T3 & 10 & 1 & 9 & 0.309 \\
\hline \multicolumn{5}{|c|}{ GRADE } \\
\hline G2 & 15 & 5 & 10 & \\
\hline G3 & 41 & 7 & 34 & 0.171 \\
\hline \multicolumn{5}{|c|}{ LYMPH NODE } \\
\hline N0 & 33 & 5 & 28 & \\
\hline N1 & 9 & 3 & 6 & \\
\hline $\mathrm{N} 2$ & 8 & 3 & 5 & \\
\hline N3 & 6 & 1 & 5 & 0.445 \\
\hline \multicolumn{5}{|l|}{ MIB\% } \\
\hline$<14 \%$ & 25 & 9 & 16 & \\
\hline$>14 \%$ & 31 & 3 & 28 & 0.019 \\
\hline \multicolumn{5}{|l|}{ EGFR } \\
\hline$<15 \%$ & 23 & 3 & 20 & \\
\hline$>15 \%$ & 33 & 9 & 24 & \\
\hline
\end{tabular}


Prevalence: $10 \%$ was taken as threshold to define AR positivity. 26.7\% (15/56) of TNBC were AR positive, of which $21.4 \%(12 / 56)$ were AR positive with $>10 \%$ of cells and 5.3\% (3/56) cases were AR positive with $<10 \%$ of cells.

Age: mean age of TNBC patients was $52.52 \mathrm{yrs}$. AR was predominantly positive in older women $(\mathrm{p}=0.393)$ Figure-15 Age wise distribution of AR positivity

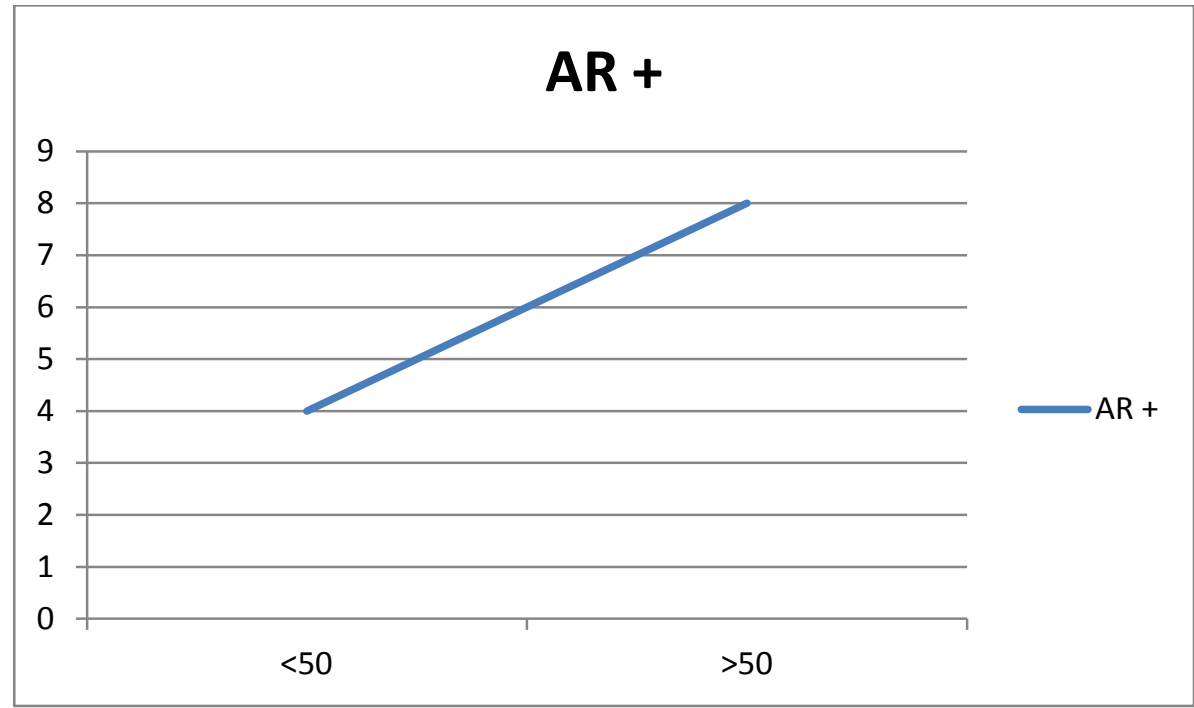

Tumor size: in AR positive TNBC patients tumor size was predominantly T2 $(\mathrm{p}=0.309)$

Figure-16 tumor size distribution in AR positive cases

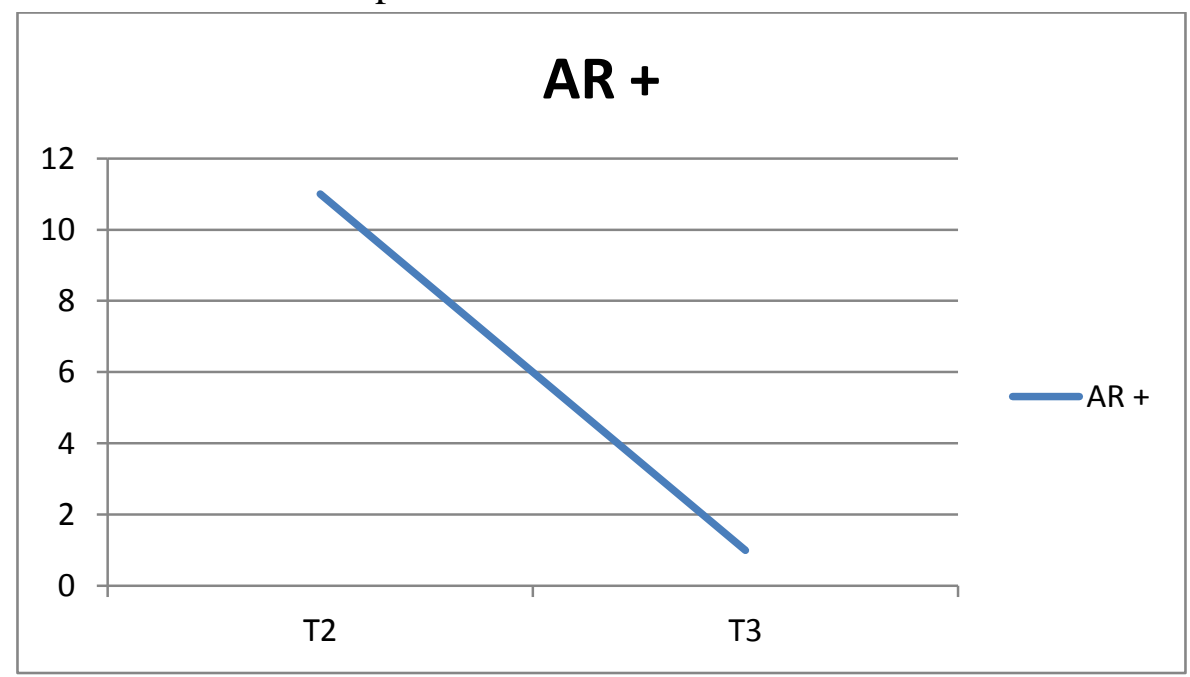

Grade: in AR positive TNBC patients, 7 patients were grade 3 and 5 patients were grade2, indicating higher grade predominance in AR positive patients. $(\mathrm{p}=0.171)$. Overall TNBC have higher grade. 
Figure-17 tumor grade distribution in AR positive cases

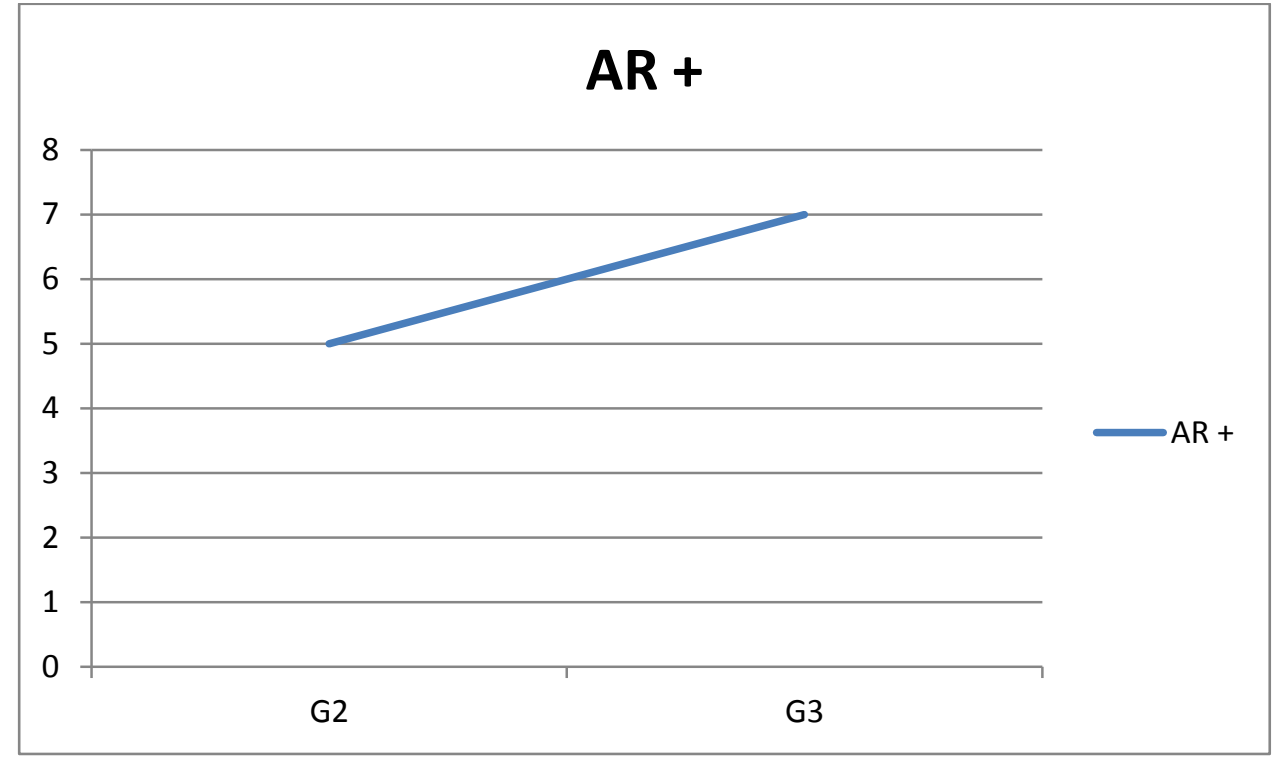

Lymph node: in AR positive patients 5 patients were N0, 3 patients were N1, 3 patients were N2 and 1 patient was N3 $(\mathrm{p}=0.445)$. There wasn't any significant association between AR positivity and lymph node metastasis.

MIB\%: there was an inverse relation between AR positivity and MIB\%. Lesser the MIB\% more the AR positivity $(\mathrm{p}=0.019)$

Figure-18 MIB distribution in AR positive cases

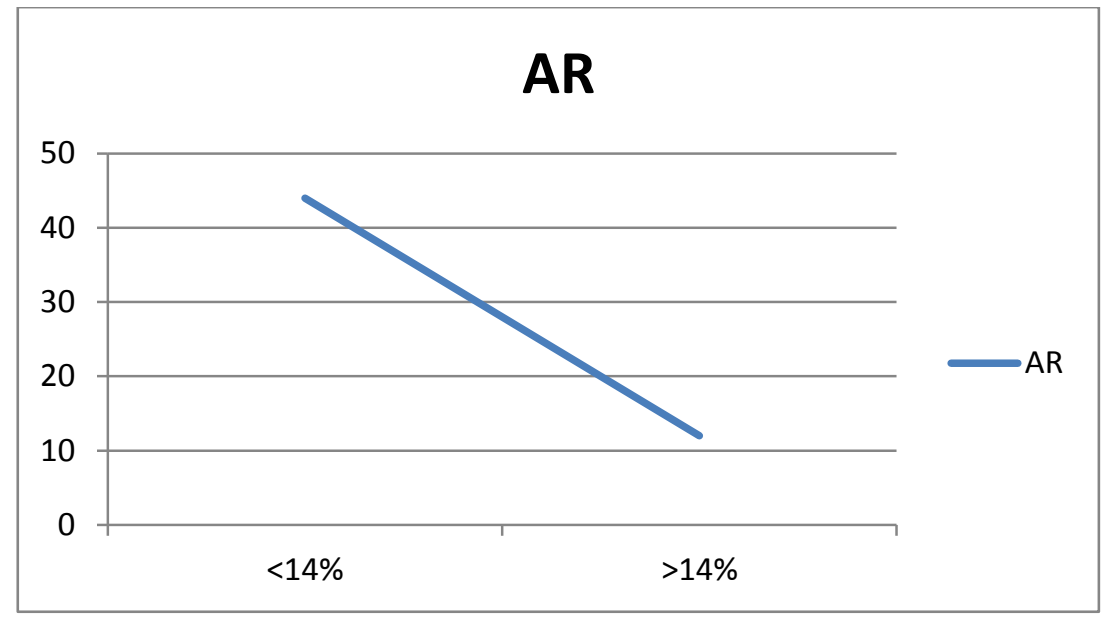

EGFR: $15 \%$ cut off was taken for EGFR positivity, almost all the TNBCs expressed basal marker EGFR. Among 12 AR positive cases, 9 patients were EGFR positive, and 3 patients were EGFR negative $(\mathrm{p}=0.173)$. Though $25 \%$ patients did not show basal phenotype but $75 \%$ of patients were $\mathrm{AR}+$, which is a significant value and cannot be ignored, these patients can be considered for targeted therapy.3 cases which were medullary and papillary phenotype on histology were negative for EGFR expression indicating there low grade nature and good prognosis. Though these cases are triple negative but not basal like.

To summarize the results, of all the parameters AR showed significant association with MIB\%. AR association with other parameters showed as its positivity is more in elderly women, higher grade, lower tumor size and lower lymph node status. Other parameters did not get significant value because of low sample size and poor patient compliance in a tertiary health care center. 


\section{JMSCR VoI||09||Issue||06||Page 225-240||June}

EGFR did not reveal any significant association with any of the parameters.

\section{Microscopic images}

Figure-20: 40 year old female showing high grade IDC, with AR positive and EGFR negative
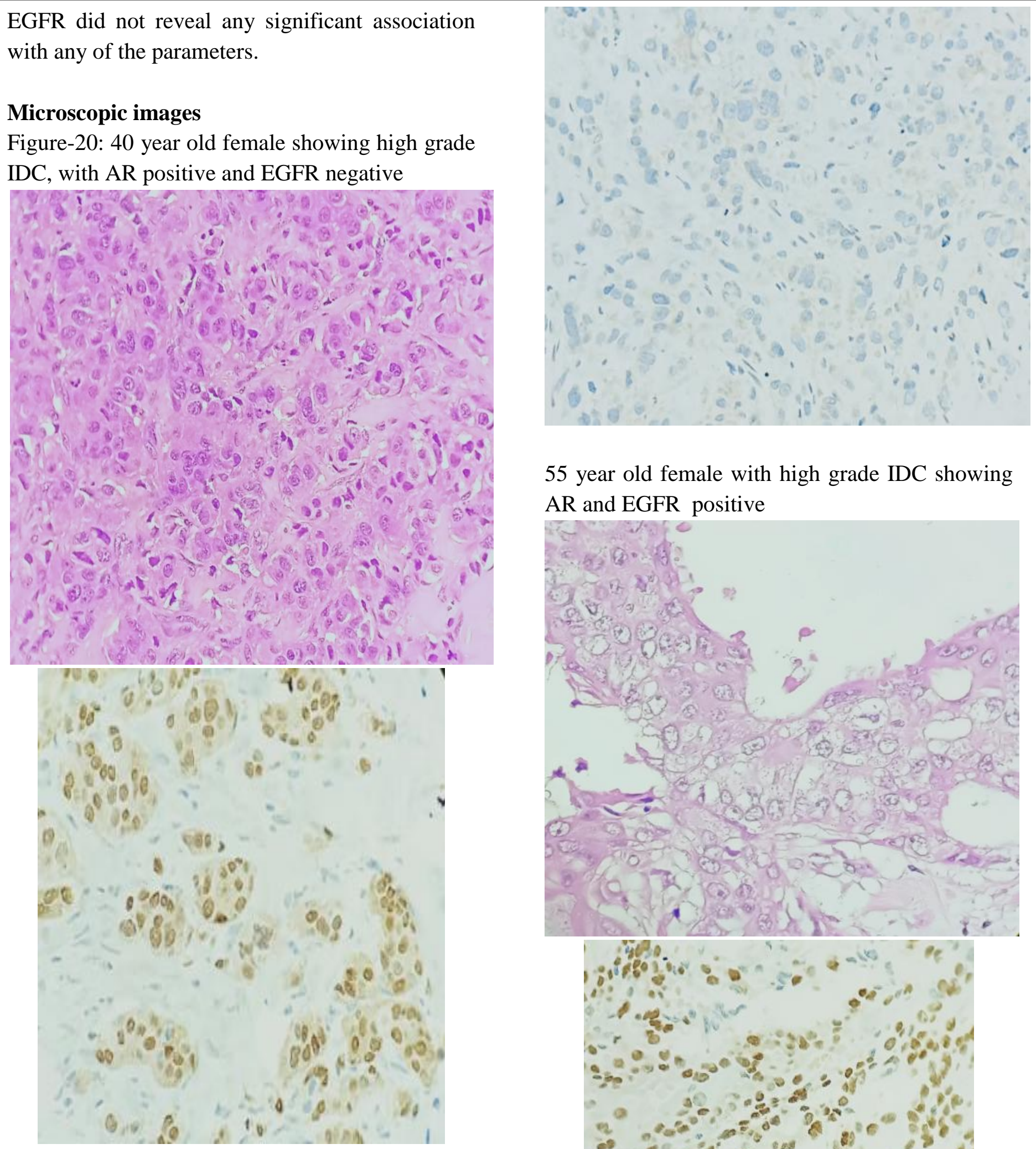

55 year old female with high grade IDC showing $\mathrm{AR}$ and EGFR positive

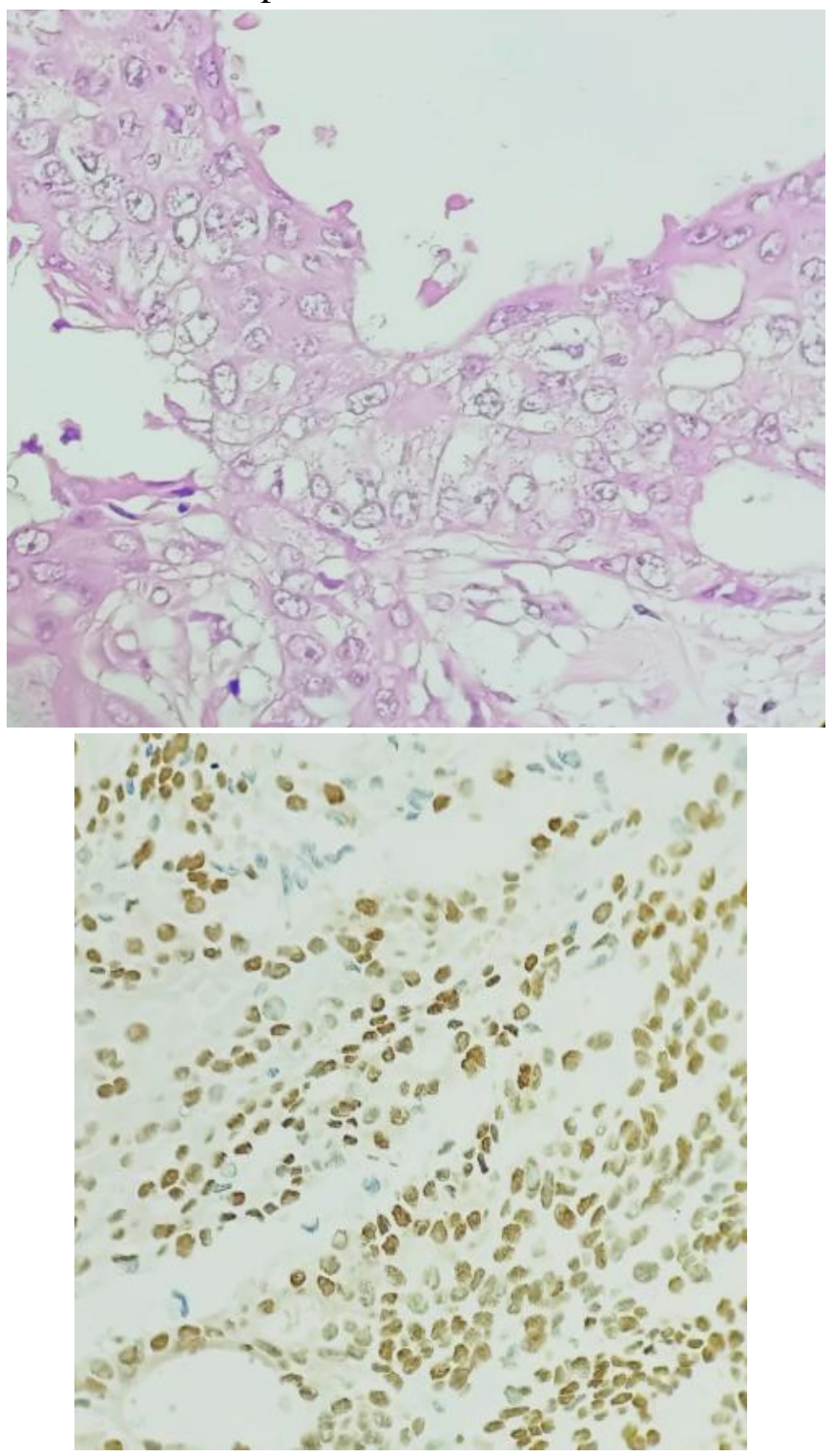




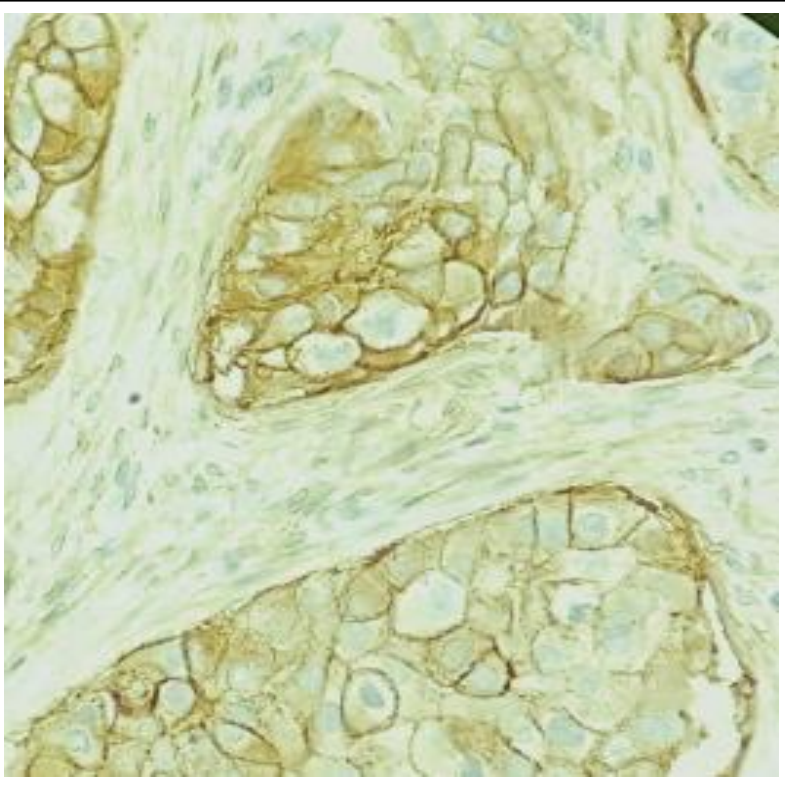

30 years old female with IDC medullary type showing AR and EGFR negative

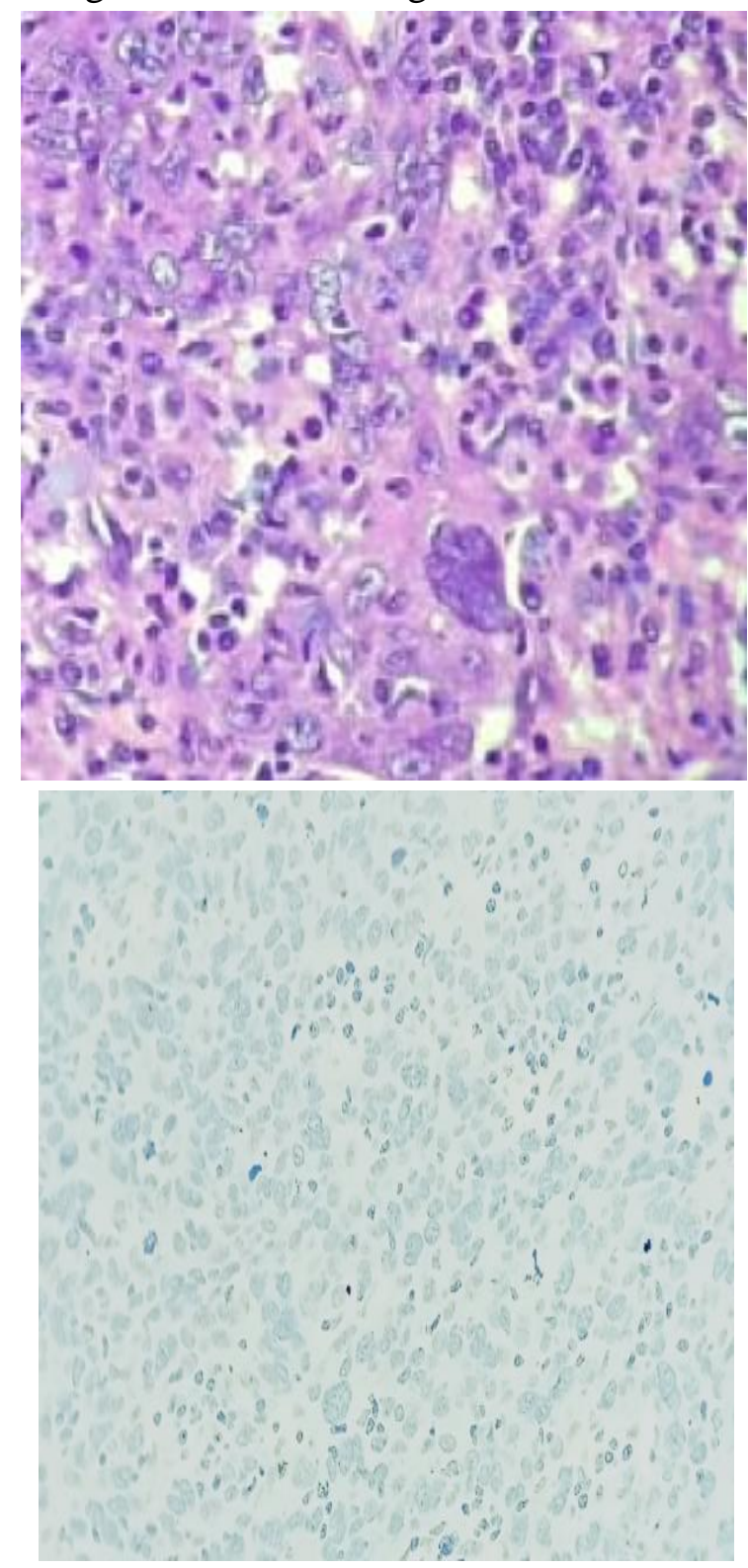

68 year old female with high grade IDC, showing AR negative and EGFR positive

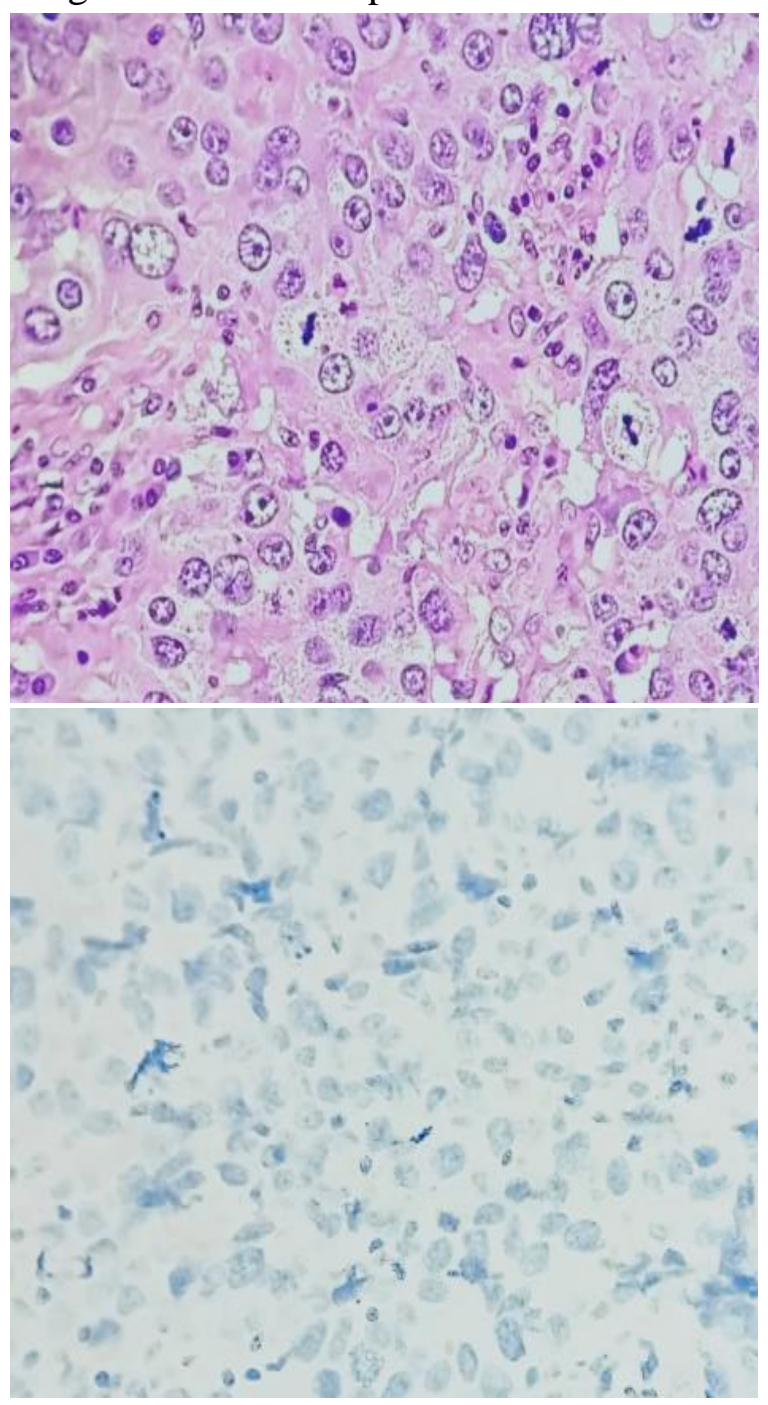




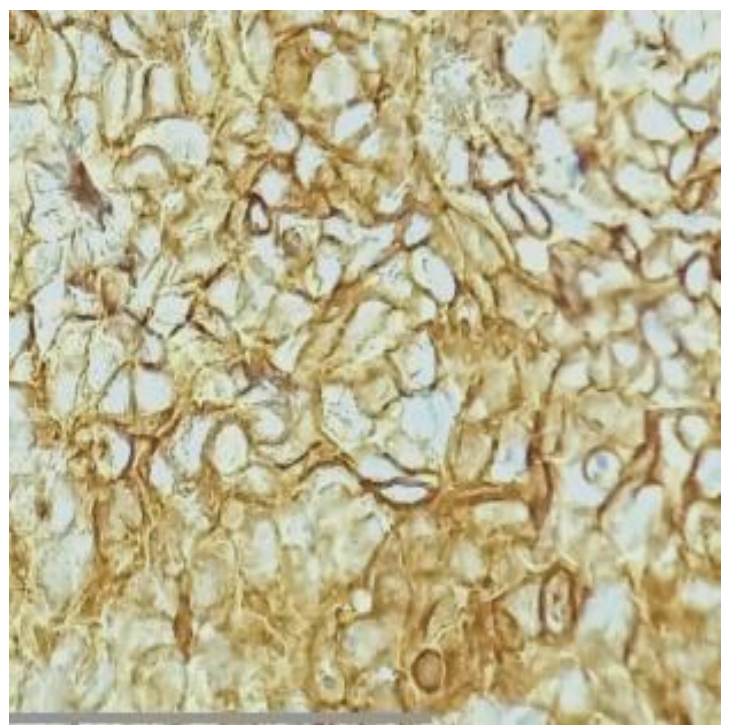

AR positivity seen in normal breast ductal elements

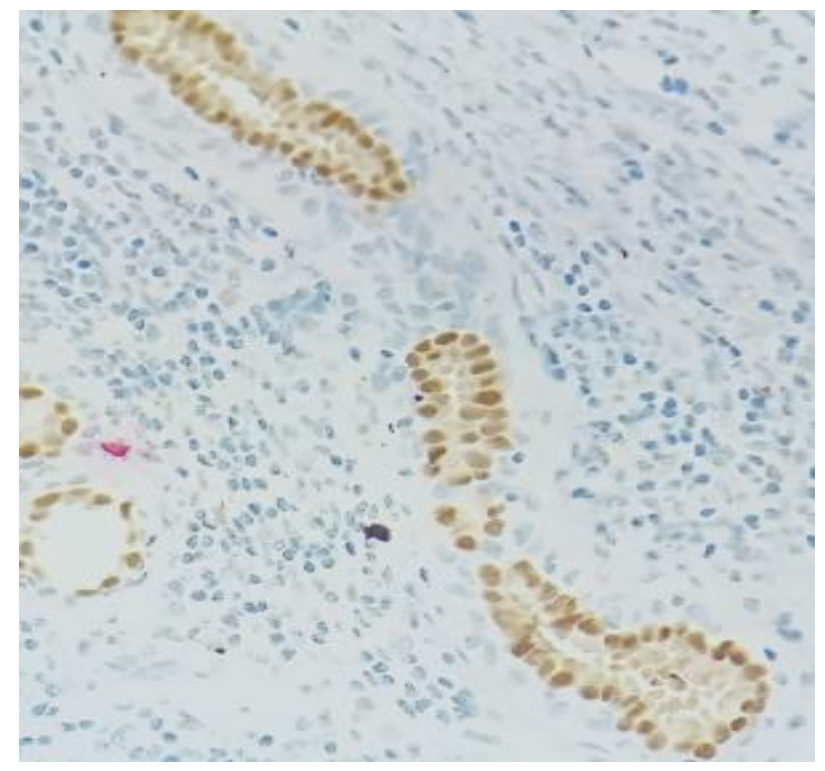

\section{Gross Images}

Right modified radical mastectomy

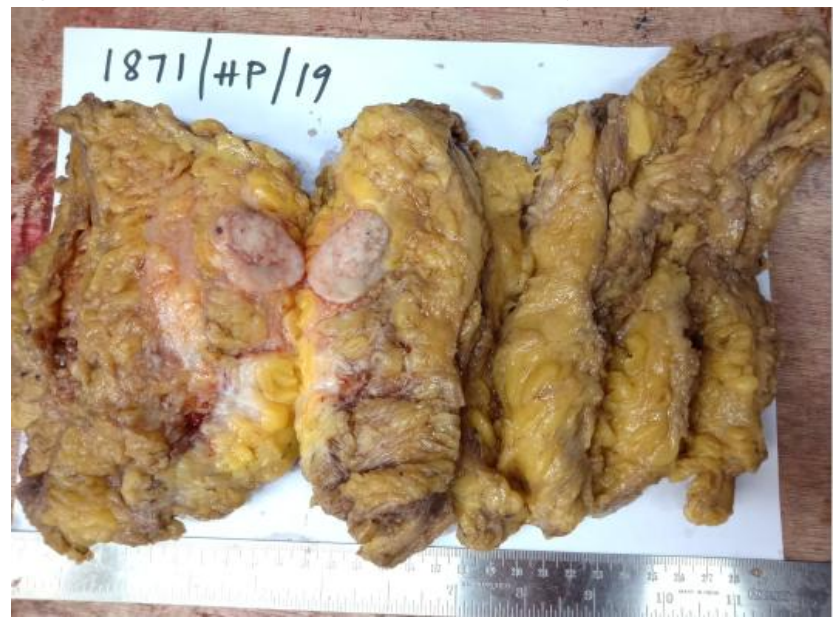

Right modified radical mastectomy

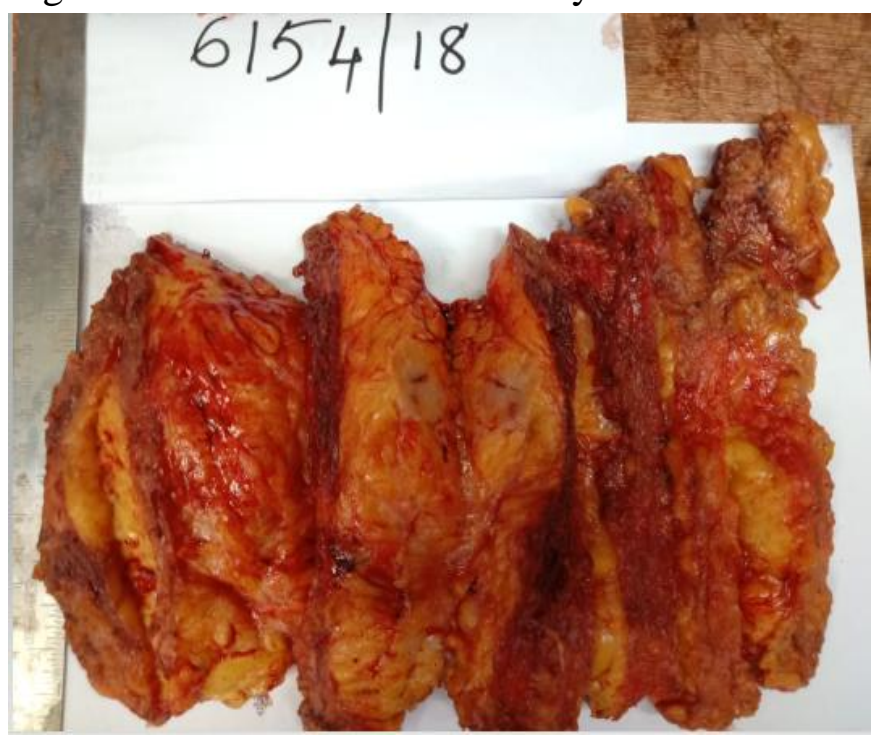

\section{TMA Blocks and Slides}
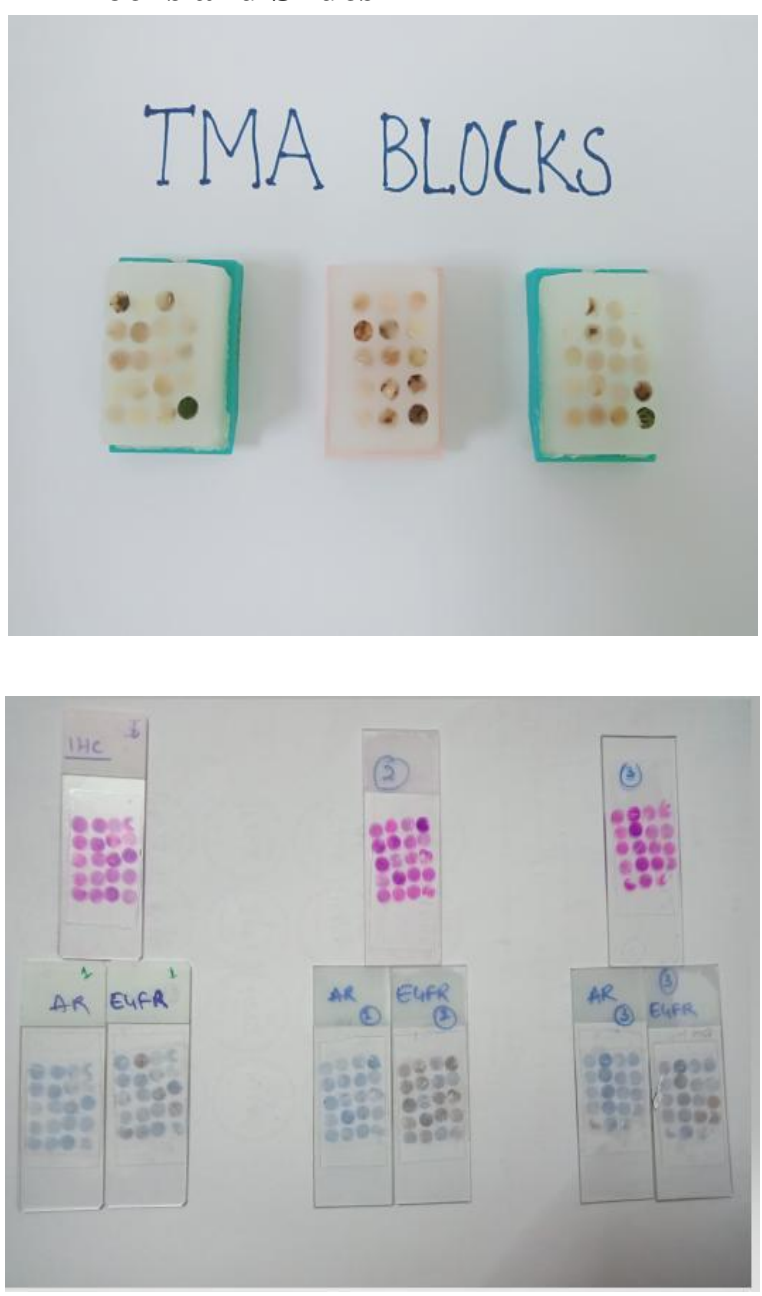

\section{Discussion}

Androgen receptor is normally present in nuclei of mammary gland tissue epithelial cells. Studies have demonstrated AR is seen in nuclei of ductal and alveolar cells by immunohistochemistry ${ }^{10-14}$. 
Few studies have showed that androgens oppose estrogens in the mammary gland. Studies conducted on rhesus monkeys demonstrated the inhibiting influence of androgens on mammary epithelial proliferation by reducing estrogen induced proliferation ${ }^{15,16}$. Similar results were seen in rodent mammary gland ${ }^{17}$.

The effects of androgens on breast cancer cell lines depends on the presence of the $A R$, the concentration of androgen and type of androgen used along with the presence of co-regulatory proteins ${ }^{18}$. In addition, apoptotic effects of androgens on breast cancer cell lines have been demonstrated ${ }^{19}$. Similar findings have been seen in cancer cells of the prostate ${ }^{20}$.

Androgen receptor plays a key role in mammary gland development like ductal branching, formation of milk producing alveoli and lobuloalveolar development ${ }^{21}$.There are few clinical evidences indicating role of AR in cancer progression $^{22-24}$. In present study, the expression of $\mathrm{AR}$ in $56 \mathrm{TNBC}$ patients was determined using immunohistochemistry.

Our data revealed $21.4 \%$ of 56 TNBC cases are positive for AR expression. This was consistent with previous findings that $10-53 \%$ of TNBC tumors express $\mathrm{AR}^{25-27}$.In present study all TNBC cases were diagnosed following the most recent guidelines recommended for evaluation of ER, PR, HER2NEU, AR and EGFR ${ }^{28-29}$.

These results of present study showed that AR is detected more frequently in smaller tumors, in cases with no lymph node metastasis, higher histologic grade and with low MIB.

Basal like breast carcinomas generally characterized by lack of hormone receptor expression and show positive expression for basal epithelial cell markers. EGFR marker which can be overexpressed in basal like carcinoma of breast included in our study, it was expressed in $58.9 \%$ of all triple negative cases. EGFR is expressed in high grade tumours and the tumors have tendency to metastasis. Thus it is useful clue to predict the tumour nature. EGFR was expressed in $75 \%$ of AR positive cases, indicating significant association. Though EGFR targeted therapy trails was conducted but the results was not satisfactory. One of the hypothesis states that the chemotherapy drugs acts more on AR-cells than $\mathrm{AR}+$ cells, resulting in the up regulation of $\mathrm{AR}$ gene expression and AR+ cells exhibiting chemotherapeutics resistance $^{30}$, thus AR hormone receptor negative breast cancers have more chances to benefit from chemotherapy. Chemotherapy insensitive or resistant triplenegative breast cancer may have high levels of AR expression; that's why, AR-targeted therapy may be used in AR+ TNBC, which poorly responds to chemotherapy.

In ER-negative TNBC, AR provokes tumor growth by stimulating the ER signaling pathway ${ }^{87}$. As in molecular apocrine profile (ER-, AR+), it shows a high invasive capability and poor prognosis $^{31}$. $90 \%$ of patients with TNBC have genetic alterations like mutations, deletions or amplifications ${ }^{32}$.

Prostate cancer is the second most common cancer among males in worldwide and it is also a hormone dependent cancer $^{33}$, and modifying the androgen levels can be useful in the treatment of prostatic carcinoma ${ }^{34}$. Therefore, AR targeted therapy can be productive in a particular group of patients, those with AR+ TNBC may have increase chances of survival rates. By using bicalutamide in treatment of prostate carcinoma archived great results ${ }^{35}$, numerous preclinical or clinical studies were conducted for using AR antagonists in TNBC (53-57). LAR breast cancer cell lines are sensitive to AR antagonists. On Further, study Cuenca-Lopez et al ${ }^{36}$ reported that AR+ TNBC cell line, those which do not belong to the LAR subtype, also are sensitivity to AR antagonists. In early clinical trials, patients with advanced AR+ TNBC were treated with bicalutamide with a clinical benefit rate of $20 \%{ }^{37}$. In a phase II clinical trial of enzalutamide, which has a six-fold higher affinity to AR than bicalutamide, $42 \%$ of patients with advanced AR+ TNBC acheived a clinical benefit time of 16 weeks in the initial data ${ }^{38}$. 
Selective androgen receptor modulators (SARMs) are novel AR-targetted therapies, which have high specificityfor AR without masculinizing side effects. Additionally, SARMs improve the side effects of advanced breast cancer by increasing muscle mass and restoring bone mineral density ${ }^{39}$. The study of Lehmann et $\mathrm{al}^{40}$, discovered that in $\mathrm{AR}+\mathrm{TNBC}$ cells, PI3K/mTOR inhibitors in combination with an AR antagonist had an additional growth inhibitory effect.

In TNBC tumors, it was seen that positivity by $\mathrm{AR}$ immunostaining is a favorable prognostic factor and was associated with a lower clinical stage, higher histologic grade, and lower proliferation index.

Absence of AR expression is associated with an increased risk for recurrence and distant metastasis in lymph node-positive TNBCs ${ }^{41,42}$.

Similarly, Luo and colleagues have shown AR expression to be correlated with higher 5-year disease-free survival (DFS) and overall survival (OS) in patients with $\mathrm{TNBC}^{43}$.

Routine AR evaluation in TNBC by IHC will provide further awareness in this path.

\section{Newer treatment strategies}

In addition to single-agent studies, significant interest is being shown in potential strategies combining AR antagonists with other targeted treatments. Lehmann and colleagues have found AR-positive TNBC tumors to have a higher frequency of phosphatidylinositol-4,5bisphosphate 3-kinase, catalytic subunit alpha gene (PIK3CA) mutations compared with ARnegative tumors ( $40 \%$ vs $4 \%$ ), and these are often associated with concurrent amplification of the PIK3CA locus. In cell line models and xenograft studies, combining bicalutamide with a panphosphoinositide 3-kinase (PI3K) inhibitor or a dual $\mathrm{PI} 3 \mathrm{~K} /$ mammalian target of rapamycin (mTOR) inhibitor has shown additive effects. This has resulted in studies assessing combinations of AR-targeted therapies with $\mathrm{PI} 3 \mathrm{~K} / \mathrm{mTOR}$ inhibitors in advanced AR-positive TNBC tumors $^{44}$. A phase $1 \mathrm{~b} / 2$ clinical trial of taselisib, a $\mathrm{PI} 3 \mathrm{~K}$ inhibitor, in combination with enzalutamide in advanced TNBC is currently recruiting patients (NCT02457910) ${ }^{45}$.Cyclin-dependent kinases 4 and 6 (CDK4 and CDK6), activated by cyclin D, promote cell cycle entry by phosphorylating $\mathrm{Rb}$ (retinoblastoma) and other proteins to initiate transition from the G1 phase to the $S$ phase ${ }^{46}$.

This pathway is disrupted in many human cancers, leading to unrestrained cell proliferation ${ }^{47}$. After showing encouraging preclinical efficacy in breast cancer, several inhibitors of CDK4 and CDK6 are currently in varying stages of development ${ }^{48}$. Based on the significant improvement seen in PFS, the CDK4/6 inhibitor palbociclib (Ibrance, Pfizer) has been approved for the frontline treatment of advanced ER-positive breast cancer in combination with letrozole ${ }^{49}$. Recent data also support the role of palbociclib with fulvestrant (Faslodex, AstraZeneca) in patients who have had prior progression on endocrine therapy ${ }^{50}$. Although TNBC has an inherently higher proliferation rate, limited activity has been seen in preclinical studies with CDK4/6 inhibitors in unselected TNBC tumors. However, more recently, the LAR subtype of TNBC has been shown to be particularly susceptible to CDK4/6 inhibition $^{51}$.

\section{Conclusion}

Anti- AR therapy has been a significant advancement in the treatment of TNBC tumors considering the fact that lack of targeted therapy for TNBC. AR represents a novel targeted therapy in TNBC, which has an otherwise poor prognosis. Based on the reliable clinical data and immunohistochemistry results, we expect that the newer, more potent anti-androgens will significantly improve the outcomes and make the targeted therapy available for what to date has been an orphan disease.

\section{Bibliography}

1. Shreshthamalva, et al. Epidemology of breast cancer in Indian women. Ascianpacific journal of clinical oncology 2017,13,289-295. 
2. Torre LA, Bray F, Siegel RL, Ferlay J, Lortet-Tieulent $\mathrm{J}$ and Jemal A: Global cancer statistics, 2012. CA Cancer J Clin 65: 87-108, 2015

3. Siegel RL, Miller $\mathrm{KD}$ and Jemal A: Cancer statistics, 2018. CA Cancer J Clin 68: 7-30, 2018

4. john Hopkins medicine and pathology, types of breast cancer.

5. New ASCO guidelines call for determining HER2 status of every invasive breast cancer, 23-oct-2013.

6. Sternberg, Stephen S., Stacey E Mills, and Darryl Carter. Sternberg's Diagnostic SurgicalPathology. 6th ed. Philadelphia: Wolters Kluwer Health/Lippincott Williams \& Wilkins, 2015

7. Adidayo A .onitilo, MD, MSCR, FACP, etal .Breast cancer subtypes based on ER/PR and HER2 expression, comparision of clinicopathological features and survival-2008 clinical medicine and research -13 , volume 7 , number $1 / 2,4$.

8. Murtuzarampurwala, et al. role of androgen receptor in triple negative breast cancer, clinical advances in haematology and oncology march 2016 volume 14, issue 3.

9. Ashwanik. mishra, et al. Expression of androgen receptor in breast carcinoma and its correlation with other steroid receptors and growth factors.Inj J med Res 135 june 2012 pp 843-852.

10. Zhuang Y, Saaristo R, Ylikomi T: An in vitro longterm culture model for normal human mammary gland: expression and regulation of steroid receptors. Cell Tissue Res 2003;311:217-226

11. Ruizeveld de Winter JA, Trapman J, Vermey M, Mulder E, Zegers ND, van der Kwast TH: Androgen receptor expression in human tissues: an immunohistochemical study. J Histochem Cytochem 1991;39:927-936.
12. Kimura N, Mizokami A, Oonuma $\mathrm{T}$, Sasano H, Nagura H: Immunocytochemical localization of androgen receptor with polyclonalantibody in paraffin-embedded human tissues. $\mathrm{J}$ Histochem Cytochem 1993;41:671-678.

13. Janssen PJ, Brinkmann AO, Boersma WJ, Van der Kwast TH: Immunohistochemical detection of the androgen receptor with monoclonal antibody F39.4 in routinely processed, paraffin-embedded human tissues after microwave pre-treatment. J Histochem Cytochem 1994;42:1169-1175.

14. Birrell SN, Butler LM, Harris JM, Buchanan G, Tilley WD: Disruption of androgen receptor signaling by synthetic progestins may increase risk of developing breast cancer. FASEB J 2007;21: 22852293. 36 Riva C, Dainese E, Caprara G, Rocca PC, Massarel

15. Zhou J, Ng S, Adesanya-Famuiya O, Anderson K, Bondy CA: Testosterone inhibits estrogen-induced mammary epithelial proliferation and suppresses estrogen receptor expression. FASEB J 2000;14: 1725-1730.

16. Dimitrakakis C, Zhou J, Wang J, Belanger A, LaBrie F, Cheng C, Powell D, Bondy $\mathrm{C}$ : A physiologic role for testosterone in limiting estrogenic stimulation of the breast. Menopause 2003;10: 292-298.

17. Jayo MJ, Register TC, Hughes CL, BlasMachado U, Sulistiawati E, Borgerink H, Johnson CS: Effects of an oral contraceptive combination with or without androgen on mammary tissues: a study in rats. J Soc Gynecol Investig 2000;7:257265.

18. Somboonporn W, Davis SR: Testosterone effects on the breast: implications for testosterone therapy for women. Endocr Rev 2004;25:374-388.

19. Lapointe J, Fournier A, Richard V, Labrie $\mathrm{C}$ : Androgens down-regulate bcl-2 protooncogene expression in ZR-75-1 
human breast cancer cells. Endocrinology 1999;140:416-421.

20. Hatzoglou A, Kampa M, Kogia C, Charalampopoulos I, Theodoropoulos PA, Anezinis P, Dambaki C, Papakonstanti EA, Stathopoulos EN, Stournaras C, Gravanis A, Castanas E: Membrane androgen receptor activation induces apoptotic regression of human prostate cancer cells in vitro and in vivo. J Clin Endocrinol Metab 2005;90:893-903.

21. Yeh S, Hu Y, Wang P, Xie C, Xu Q, Tsai M, Dong Z, Wang R, Lee T and Chang C: Abnormal mammary gland development and growth retardation in female mice and MCF7 breast cancer cells lacking androgen receptor. J Exp Med 198: 18991908, 2003

22. Lehmann BD, Bauer JA, Chen X, Sanders ME, Chakravarthy AB, Shyr Y and Pietenpol JA: Identification of human triple-negative breast cancer subtypes and preclinical models for selection of targeted therapies. J Clin Invest 121: 2750-2767, 2011.

23. Chia KM, Liu J, Francis GD and Naderi A: A feedback loop between androgen receptor and ERK signaling in estrogen receptor-negative breast cancer. Neoplasia 13: 154-166, 2011.

24. Robinson JL, Macarthur S, Ross-Innes CS, Tilley WD, Neal DE, Mills IG and Carroll JS: Androgen receptor driven transcription in molecular apocrine breast cancer is mediated by FoxA1. EMBO J 30: 30193027, 2011.

25. Qi JP, Yang YL, Zhu H, Wang J, Jia Y, Liu N, Song YJ, Zan LK, Zhang X, Zhou $M$, et al: Expression of the androgen receptor and its correlation with molecular subtypes in 980 chinese breast cancer patients. Breast Cancer (Auckl) 6: 1-8, 2012.

26. Rakha EA, El-Sayed ME, Green AR, Lee $\mathrm{AH}$, Robertson JF and Ellis IO: Prognostic markers in triple-negative breast cancer. Cancer 109: 25-32, 2007.

27. Choi JE, Kang SH, Lee SJ and Bae YK: Androgen receptor expression predicts decreased survival in early stage triplenegative breast cancer. Ann Surg Oncol 22: 82-89, 2015.

28. Wolff AC, Hammond ME, Hicks DG, Dowsett M, McShane LM, Allison KH, Allred DC, Bartlett JM, Bilous M, Fitzgibbons P, et al: Recommendations for human epidermal growth factor receptor 2 testing in breast cancer: American Society of Clinical Oncology/College of American Pathologists clinical practice guideline update. Arch Pathol Lab Med 138: 241256, 2014.

29. Hammond ME, Hayes DF, Dowsett M, Allred DC, Hagerty KL, Badve S, Fitzgibbons PL, Francis G, Goldstein NS, Hayes M, et al: American Society of Clinical Oncology/College of American Pathologists guideline recommendations for immunohistochemical testing of estrogen and progesterone receptors in breast cancer (unabridged version). Arch Pathol Lab Med 134: e48-e72, 2010.

30. Lehmann BD and Pietenpol JA: Identification and use of biomarkers in treatment strategies for triple-negative breast cancer subtypes. J Pathol 232: 142150, 2014.

31. Doane AS, Danso M, Lal P, Donaton M, Zhang L, Hudis C and Gerald WL: An estrogen receptor-negative breast cancer subset characterized by a hormonally regulated transcriptional program and response to androgen. Oncogene 25: 39944008, 2006.

32. Tsutsumi Y: Apocrine carcinoma as triplenegative breast cancer: Novel definition of apocrine-type carcinoma as estrogen/progesterone receptor-negative and androgen receptor-positive invasive 
ductal carcinoma. Jpn J Clin Oncol 42: 375-386, 2012.

33. Xu H, Eirew P, Mullaly SC and Aparicio S: The omics of triple-negative breast cancers. ClinChem 60: 122-133, 2014.

34. Siegel RL, Miller KD and Jemal A: Cancer statistics, 2018. CA Cancer J Clin 68: 7-30, 2018

35. Komura K, Sweeney CJ, Inamoto T, Ibuki $\mathrm{N}$, Azuma $\mathrm{H}$ and Kantoff PW: Current treatment strategies for advanced prostate cancer. Int J Urol, 2017.

36. Loblaw DA, Virgo KS, Nam R, Somerfield MR, Ben-Josef E, Mendelson DS, Middleton R, Sharp SA, Smith TJ, Talcott $\mathrm{J}$, et al: Initial hormonal management of androgen-sensitive metastatic, recurrent, or progressive prostate cancer: 2006 update of an American Society of Clinical Oncology practice guideline. J ClinOncol 25: 15961605, 2007.

37. Cuenca-López MD, Montero JC, Morales JC, Prat A, Pandiella A and Ocana A: Phospho-kinase profile of triple negative breast cancer and androgen receptor signaling. BMC Cancer 14: 302, 2014.

38. Gucalp A, Tolaney S, Isakoff SJ, Ingle JN, Liu MC, Carey LA, Blackwell K, Rugo H, Nabell L, Forero A, et al: Phase II Trial of bicalutamide in patients with androgen receptor-positive, estrogen receptornegative metastatic breast cancer. Clin Cancer Res 19: 5505-5512, 2013.

39. Traina TA, Miller K, Yardley DA, Eakle J, Schwartzberg LS, O'Shaughnessy J, Gradishar W, Schmid P, Winer E, Kelly C, et al: Enzalutamide for the treatment of androgen receptor-expressing triplenegative breast cancer. J ClinOncol: JCO2016713495, 2018.

40. Narayanan R, Ahn S, Cheney MD, Yepuru M, Miller DD, Steiner MS and Dalton JT: Selective Androgen receptor modulators (SARMs) negatively regulate triple- negative breast cancer growth and epithelial: Mesenchymal stem cell signaling. PLoS One 9: e103202, 2014

41. Lehmann BD, Bauer JA, Schafer JM, Pendleton CS, Tang L, Johnson KC, Chen X, Balko JM, Gómez H, Arteaga CL, et al: PIK3CA mutations in androgen receptorpositive triple negative breast cancer confer sensitivity to the combination of PI3K and androgen receptor inhibitors. Breast Cancer Res 16: 406, 2014

42. Rakha EA, El-Sayed ME, Green AR, Lee AH, Robertson JF, Ellis IO. Prognostic markers in triple-negative breast cancer.Cancer. 2007;109(1):25-32.

43. Sutton LM, Cao D, Sarode V, et al. Decreased androgen receptor expression is associated with distant metastases in patients with androgen receptor-expressing triple-negative breast carcinoma. Am J ClinPathol. 2012;138(4):511-516.

44. Luo X, Shi YX, Li ZM, Jiang WQ. Expression and clinical significance of androgen receptor in triple negative breast cancer. Chin J Cancer. 2010;29(6):585590.

45. Lehmann BD, Bauer JA, Schafer JM, et al. PIK3CA mutations in androgen receptorpositive triple negative breast cancer confer sensitivity to the combination of PI3K and androgen receptor inhibitors. Breast Cancer Res. 2014;16(4):406.

46. Clinical Trials.gov. Taselisib and enzalutamide in treating patients with androgen receptor positive triple-negative metastatic breast cancer. https:// clinicaltrials.gov/ct2/results?term=NCT02 457910\&Search=Search. Identifier: NCT02457910. Accessed January 29, 2016.

47. Asghar U, Witkiewicz AK, Turner NC, Knudsen ES. The history and future of targeting cyclin-dependent kinases in cancer therapy. Nat Rev Drug Discov. 2015;14(2):130-146. 
48. Dickson C, Fantl V, Gillett C, et al. Amplification of chromosome band 11q13 and a role for cyclin D1 in human breast cancer. Cancer Lett. 1995;90(1):43-50.

49. Dukelow T, Kishan D, Khasraw M, Murphy CG.CDK4/6 inhibitors in breast cancer. Anticancer Drugs. 2015;26(8):797806.

50. Finn RS, Crown JP, Lang I, et al. The cyclin-dependent kinase 4/6 inhibitor palbociclib in combination with letrozole versus letrozole alone as first-line treatment of oestrogen receptor-positive, HER2-negative, advanced breast cancer (PALOMA-1/ TRIO-18): a randomised phase 2 study. Lancet Oncol. 2015;16(1):25-35.

51. Turner NC, Ro J, André F, et al; PALOMA3 Study Group. Palbociclib in Hormone Receptor-Positive Advanced Breast Cancer. N Engl J Med. 2015;373(3):209-219.

52. Asghar U, Herrera-Abreu MT, Cutts R, et al. Identification of subtypes of triple negative breast cancer (TNBC) thatare sensitive to CDK4/6 inhibition [ASCO abstract 11098]. J Clin Oncol. 2015;33(15)(suppl). 